\title{
Elevated Cobalt, Chromium and Molybdenum Levels in Peripheral Blood Have No Effect on the Development of Heterotopic Ossifications after Metal-on-Metal Total Hip Arthroplasty
}

\author{
Alexander J. Pfister1, Karl-Heinz Widmer ${ }^{2}$, Niklaus F. Friederich ${ }^{3}$, \\ Martin Majewski ${ }^{3}$ \\ ${ }^{1}$ Department of Anaesthesiology, Hospital of Bülach, Bülach, Switzerland \\ ${ }^{2}$ Department of Orthopaedic Surgery and Traumatology, Hospital of Schaffhausen, Schaffhausen, Switzerland \\ ${ }^{3}$ Department of Orthopaedic Surgery and Traumatology, University of Basel, Basel, Switzerland \\ Email: Martin.Majewski@usb.ch
}

Received 17 December 2015; accepted 24 January 2016; published 28 January 2016

Copyright (C) 2016 by authors and Scientific Research Publishing Inc.

This work is licensed under the Creative Commons Attribution International License (CC BY).

http://creativecommons.org/licenses/by/4.0/

c) (7) Open Access

\begin{abstract}
Metal debris from metal-on-metal (MoM) total hip arthroplasties (THA) has been suspected to cause periprosthetic heterotopic ossifications (HO). We determined the influence of disseminated cobalt, chromium and molybdenum on the development of HO. Native blood samples from patients with 86 high-carbon and 16 low-carbon $\mathrm{Co}_{28} \mathrm{Cr}_{6} \mathrm{Mo}$ articulations were analysed by highresolution inductively coupled plasma mass-spectrometry (HR ICP-MS). The results revealed that high-carbon metal-on-metal articulations showed lower metal blood levels (Co 1.03 to $1.60 \mu \mathrm{g} / \mathrm{l}$, Cr 0.77 to $0.88 \mu \mathrm{g} / \mathrm{l}$, Mo 0.45 to $0.56 \mu \mathrm{g} / \mathrm{l}$ ) whereas low-carbon articulations achieved higher metal blood levels (Co 2.59 to $6.85 \mu \mathrm{g} / \mathrm{l}, \mathrm{Cr} 1.25$ to $3.55 \mu \mathrm{g} / \mathrm{l}$, Mo 0.45 to $0.64 \mu \mathrm{g} / \mathrm{l}$ ), but no correlation between metal ion blood level or carbon content and the development of $\mathrm{HO}$ could be found in these MoM articulations. Hence, metal debris from MoM articulation does not stimulate heterotopic bone formation despite other well-known local reactions.
\end{abstract}

\section{Keywords}

Wear, Total Hip Arthroplasty, Cobalt, Chromium, Molybdenum, Heterotopic Ossification

How to cite this paper: Pfister, A.J., Widmer, K.-H., Friederich, N.F. and Majewski, M. (2016) Elevated Cobalt, Chromium and Molybdenum Levels in Peripheral Blood Have No Effect on the Development of Heterotopic Ossifications after Metalon-Metal Total Hip Arthroplasty. J. Biomedical Science and Engineering, 9, 25-40.

http://dx.doi.org/10.4236/jbise.2016.91004 


\section{Introduction}

Cobalt-based alloys have been proposed and used in high-demanding applications for as long as investment casting has been available as an industrial process. From the introduction of Stellite ${ }^{\circledR}$ in the late 1920 s, cobalt alloys have contributed significantly to dental applications. In the late 1970s CoCrMo alloys competed directly with titanium and wrought (drop-forged) CoCrMo alloys for medical implant devices. Cast CoCrMo alloys were basically abandoned in favour of wrought alloys not only because of their higher strength but also because of their hysteresis and thus their superior corrosion characteristics [1]-[3]. Due to their poor long-term survivorship, the early total hip arthroplasties (THA) with large ball metal-on-metal articulations remained of minor importance and fell into general disuse in the 1970s. Nevertheless, analyses of numerous retrievals from the first-generation low-carbon metal-on-metal articulations showed very low linear wear rates and hardly any periprosthetic osteolysis [4] [5]. Inspired by these observations, a second generation of metal-on-metal articulations was developed based on wrought $\mathrm{Co}_{28} \mathrm{Cr}_{6}$ Mo alloy [6]-[10] in the 1980s. They were implanted in the 1990s and thorough analyses of respective retrievals showed nearly unscratched bearing surfaces and again very low linear wear rates of 2 to $5 \mu \mathrm{m}$ per year [8].

Although these newer metal-on-metal articulations showed good longevity and a lower amount of debris, some inevitable problems are persisting. The metal debris contributes to metal ion levels, to the formation of organo-metallic complexes and inorganic metal salts; it is subject to oxidative changes and it is known to be transformed into organic storage forms, such as hemosiderin [11]-[18]. Therefore, possible regional and systemic effects must be considered owing to the possible reactivity and/or toxicity of this metallic debris and interactions with metabolic, bacteriological and immunological processes cannot be ruled out [13] [18]. Furthermore, most constituents of the currently used alloys, as well as some corrosion products are a legitimate cause for concern in terms of toxicity, mutagenicity, neoplastic changes and hypersensitivity reactions [19]-[22]. There is no denying that some rare but severe cases of inflammatory response have been reported recently and heterotopic bone formation may be one of them [23]-[28].

The formation of ectopic or heterotopic ossifications (HO) was first described as myositis ossificans in 1868. Although ossifications associated with THA are regarded as a type of myositis ossificans circumscripta, this term is not commonly used in orthopedics. Relevant $\mathrm{HO}$ are classified into two subtypes according to their etiology in orthopedics: 1) ossifications after trauma and/or surgery and 2) neurogenous ossifications [29]. While sparse formation of ectopic bone occurs in up to $90 \%$ of all patients after THA, severe bridging formations of bone or even ankylosis are only seen in a small number of patients [30]-[33].

Microhistology of $\mathrm{HO}$ is equivalent to orthotopic bone except that a directed pattern of the trabecular bone is missing, since no directed load is applied. It should be noted that HO and heterotopic calcifications are not equal. Calcifications are the result of an increased $\mathrm{pH}$-level which gives rise to a subsequent precipitation of calcium carbonate and/or calcium phosphate. Unlike HO microhistology of calcifications does not show any characteristics of bone.

Early radiographic signs of heterotopic bone formation can be observed 3 to 8 weeks postoperatively, while first scintigraphic activity will appear 2 to 4 weeks postoperatively and can be detected for up to 12 months [30]. Scattered or smaller ossifications are either asymptomatic or tend to be painful in different degrees. Functional impairment results from ectopic formations on both sides of the genuine articulation and may lead to a functional ankylosis [33] especially when the ectopic bone is bridging the joint.

Elevated levels of alkaline phosphatase (AP) as well as C-reactive protein (CRP) in patients in the early postoperative phase after THAs are associated with a higher rate of HO [31] [34].

There is an ongoing controversy whether implant design, fixation technique and/or surgical approach might play a role in the development of HO [35]-[39]. Assured risk factors for the developing HO are: the male gender, post traumatic osteoarthritis, heterotrophic osteoarthritis, Bechterew's, Paget's and Parkinson's disease, diffuse idiopathic skeletal hyperostosis (DISH), previous ankylosis and/or preoperatively limited range of motion (ROM) and excessive osteophytosis [36] [40]-[42]. Another risk factor has been added to this list recently. It has been suspected that elevated metal levels due to the use of metal-on-metal articulations in artificial joints may cause the formation of postoperative periprosthetic HO too [43] [44].

Therefore, the aim of this retrospective study was to determine whether elevated cobalt, chromium and molybdenum levels in native blood are associated with the development and the expression of periprosthetic HO after THA with metal-on-metal articulations made of wrought low-carbon or high-carbon $\mathrm{Co}_{28} \mathrm{Cr}_{6} \mathrm{Mo}$ alloys meeting ISO 5832-12 and ASTM F-1537 standards. 


\section{Materials and Methods}

This series of consecutive THAs, which were all performed by the same team of orthopedic surgeons under the same technical conditions in an identical operating room environment, was retrospectively evaluated in a crosssectional study with a follow-up of one to six years.

All patients were given thromboembolic prophylaxis (heparinic acid, coumadine, low molecular weight heparin or combinations thereof overlapping), as well as perioperative antibiotic treatment ( $3^{\text {rd }}$ generation cephalosporin) and were mobilised the first day after surgery and routinely No standardized prophylaxis against HO was given.

Over a five-year period, in 135 out of 801 (=16.9\%) procedures, prosthetic components with a metal-on-metal articulation were routinely used with younger and more active patients. The 135 THAs were performed on 121 patients, 46 (38\%) female, 75 (62\%) male. Mean age at the time of surgery was $58.6 \mathrm{y}$ ( $\mathrm{n}=135$, range $26 \mathrm{y}$ to 89 $\mathrm{y}, \mathrm{SD} \pm 11 \mathrm{y})$. Surgery was indicated in 124 (91.9\%) primary THA, 9 (6.7\%) primary revisions and 2 (1.5\%) secondary revisions. By the time of follow-up, 39 (32.2\%) patients had bilateral THA, whereas 13 (10.7\%) received their contralateral prostheses during, and 2 (1.7\%) after the follow-up period of this study. The indications for THA are listed in Table 1. The surgical approaches were either anterolateral, modified after WatsonJones (50.4\%) or direct lateral after Hardinge (45.9\%), while a transgluteal approach after Bauer was only chosen in a minority (3.0\%) of the cases. At the time of follow-up, two patients (1.7\%) underwent revision surgery following recurrent dislocation and where thus excluded from this study. Therefore, a total of 133 arthroplasties were taken into consideration for this follow-up study.

Table 1. Indications to total hip replacement with metal-on-metal articulation $(\mathrm{n}=135)$.

\begin{tabular}{ll} 
- Primary osteoarthritis & $52.6 \%(\mathrm{n}=71)$ \\
- Secondary osteoarthritis due to ${ }^{\mathrm{a}}$ & $23.0 \%(\mathrm{n}=31)$ \\
- Slipped capital femoral epiphysis (SCFE) & $8.1 \%(\mathrm{n}=11)$ \\
- Congenital hypoplasia or dysplasia of the hip & $7.4 \%(\mathrm{n}=10)$ \\
- Closed wedge resection of the proximal femur & $5.2 \%(\mathrm{n}=7)$ \\
- Legg-Calve-Perthes disease (LCP) & $0.7 \%(\mathrm{n}=1)$ \\
- Postseptic osteoarthritis & $0.7 \%(\mathrm{n}=1)$ \\
- Acetabular fracture & $0.7 \%(\mathrm{n}=1)$ \\
- Avascular necrosis of the femoral head (AVN) & $9.6 \%(\mathrm{n}=13)$ \\
- Primary revision due to & \\
- Aseptic loosening of the acetabular component & $6.7 \%(\mathrm{n}=9)$ \\
- Loosening of the stem due to low grade infection & $5.2 \%(\mathrm{n}=7)$ \\
- Aseptic loosening of the stem & $0.7 \%(\mathrm{n}=1)$ \\
- Femoral neck fracture & \\
- Pertrochanteric & $0.7 \%(\mathrm{n}=1)$ \\
- Intertrochanteric & \\
- Medial/subcapital & \\
- Lateral/transcervical & $4.4 \%(\mathrm{n}=6)$ \\
- Rheumatoid arthritis & $2.2 \%(\mathrm{n}=3)$ \\
- Secondary revision due to ${ }^{\mathrm{a}}$ & $0.7 \%(\mathrm{n}=1)$ \\
\hline
\end{tabular}

${ }^{\mathrm{a} C o n s o l i d a t e d ~ v a l u e s ;}{ }^{\mathrm{b}}$ Endler cup $(\mathrm{n}=5)$, Tillman cup $(\mathrm{n}=1)$, acetabular component undocumented $(\mathrm{n}=1)$. 


\section{A. J. Pfister et al.}

All total hip prostheses consisted of an uncemented modular acetabular metal socket with an articulating metal inlay moulded into a polyethylene backing liner (sandwich construct) and a modular metal head (Table 2) of $28 \mathrm{~mm}$ diameter. The vast majority of the implanted 133 modular rectangular shaped titanium stems (93.2\%) were uncemented, whereas only 3.8\% were cemented. During revision surgery, $3.0 \%$ of the stems could be left in situ owing to their modularity.

The prosthetic components used for the 133 arthroplasties resulted in three different types of metal-on-metal sliding pairings all made from $\mathrm{Co}_{28} \mathrm{Cr}_{6}$ Mo alloys meeting ISO 5832-12 and ASTM F-1537 standards. Though material specifications are exactly identical, the surface properties of the applied alloys were considerably different implicating different wear behaviour. Therefore, we divided our study population into three discrete study groups (see Table 3).

A total of 113 (85.0\%) sliding pairings were made of wrought Metasul ${ }^{\circledR}$ high-carbon $\mathrm{Co}_{28} \mathrm{Cr}_{6}$ Mo alloy Protasul $^{\circledR}$ 21-WF with a carbon content of 0.25 weight-\% providing a metal matrix with fine ingot carbides. A minority of 17 (12.8\%) sliding pairings were made of wrought low-carbon $\mathrm{Co}_{28} \mathrm{Cr}_{6} \mathrm{Mo}$ alloy with a carbon content of 0.085 weight-\% resulting in a metal matrix with no carbides at all. With 3 (2.3\%) articulations, only the acetabular liner of the articulation is documented. Therefore, the type of these pairings could not be determined precisely.

In the high-carbon study group 5 patients with 5 (4.4\%) arthroplasties were dead at follow-up and 16 (14.2\%) arthroplasties were lost to follow-up. Hence, in the high-carbon group, clinical and radiological follow-up of 92 (81.4\%) arthroplasties in 89 patients was possible. Mean follow-up was $4.1 \mathrm{y}(\mathrm{n}=92$, range $0.9 \mathrm{y}$ to $5.9 \mathrm{y}, \mathrm{SD} \pm$ $1.2 \mathrm{y})$.

Table 2. Acetabular and femoral components of the metal-on-metal articulations $(n=133)$.

\begin{tabular}{|c|c|}
\hline Acetabular Components with $\mathrm{Co}_{28} \mathrm{Cr}_{6} \mathrm{MO}$ Articulation Liner ${ }^{\mathrm{a}}$ & $100 \%(n=133)$ \\
\hline Alloclassic ${ }^{\circledR}$ (Allopro ${ }^{\circledR} /$ SULZER Medica ${ }^{\circledR}$ ) modular threaded conical & $85.0 \%(n=113)$ \\
\hline titanium cup with grit blasted outer surface, after Zweymüller & \\
\hline $\begin{array}{c}\text { BICON }^{\circledR} \text { (PLUS Endoprosthetics }{ }^{\circledR} \text { ) modular threaded biconical titanium cup } \\
\text { with grit blasted outer surface, after Zweymüller }\end{array}$ & $12.8 \%(\mathrm{n}=17)$ \\
\hline $\begin{array}{l}\text { Press-fit (Protek }{ }^{\circledR} / \text { SULZER Medica }{ }^{\circledR} \text { ) hemispheric monobloc cup } \\
\text { with SulMesh }{ }^{\circledR} \text { titanium outer surface coating, after Morscher }\end{array}$ & $2.3 \%(n=3)$ \\
\hline Prosthetic $\mathrm{Co}_{28} \mathrm{Cr}_{6} \mathrm{Mo}$ Metal Heads ${ }^{\mathrm{a}}$ & $100 \%(\mathrm{n}=133)$ \\
\hline - Allopro $^{\circledR} /$ SULZER Medica ${ }^{\circledR}$ & $84.2 \%(n=112)$ \\
\hline - PLUS Endoprosthetics ${ }^{\circledR}$ & $12.8 \%(n=17)$ \\
\hline - Protek $^{\circledR} /$ SULZER Medica ${ }^{\circledR}$ & $0.8 \%(n=1)$ \\
\hline - Metal heads from unknown producer/producer not documented & $2.3 \%(n=3)$ \\
\hline Cemented and Uncemented Prosthetic Stems ${ }^{a}$ & $100 \%(n=133)$ \\
\hline - Zweymüller SL Allopro ${ }^{\circledR}$ uncemented (Allopro ${ }^{\circledR} /$ SULZER Medica ${ }^{\circledR}$ ) & $72.2 \%(n=96)$ \\
\hline • Zweymüller IMG 67 SL uncemented (PLUS Endoprosthetics ${ }^{\circledR}$ ) & $18.8 \%(n=25)$ \\
\hline - Weber-Stühmer cemented (Allopro ${ }^{\circledR} /$ SULZER Medica) & $2.3 \%(n=3)$ \\
\hline • Zweymüller IMG 67 SLR uncemented (PLUS Endoprosthetics ${ }^{\circledR}$ ) & $1.5 \%(n=2)$ \\
\hline - Centrament ${ }^{\circledR}$ cemented $\left(\right.$ Aesculap $^{\circledR}$ ) & $0.8 \%(n=1)$ \\
\hline - Morscher-Spotorno 30 cemented (Protek $^{\circledR} /$ SULZER Medica ${ }^{\circledR}$ ) uncemented (SULZER Medica ${ }^{\circledR}$ ) & $0.8 \%(n=1)$ \\
\hline - Wagner SL revision stem & $0.8 \%(n=1)$ \\
\hline - Stems left in situ and not documented & $3.0 \%(n=4)$ \\
\hline
\end{tabular}

\footnotetext{
${ }^{\mathrm{a}}$ Consolidated values.
} 
Table 3. $\mathrm{Co}_{28} \mathrm{Cr}_{6} \mathrm{Mo}$ metal-on-metal sliding pairings with different surface properties.

\begin{tabular}{|c|c|}
\hline High-Carbon $\mathrm{Co}_{28} \mathrm{Cr}_{6}$ Mo Sliding Pairings ${ }^{\mathrm{a}, \mathrm{b}}$ & $100 \%(n=113)$ \\
\hline Alloclassic ${ }^{\circledR}$ high-carbon Metasul ${ }^{\circledR}$ modular cup (Allopro ${ }^{\circledR} /$ SULZER Medica ${ }^{\circledR}$ ) & $82.0 \%(n=109)$ \\
\hline \multicolumn{2}{|l|}{ paired with high-carbon Metasul ${ }^{\circledR}$ head (Allopro ${ }^{\circledR} /$ SULZER Medica ${ }^{\circledR}$ ) } \\
\hline $\begin{array}{l}\text { High-carbon Metasul }{ }^{\circledR} \text { Press-Fit monobloc cup }\left(\text { Protek }^{\circledR} / \text { SULZER Medica }\right. \\
\text { paired with high-carbon Metasul }{ }^{\circledR} \text { head (Allopro }{ }^{\circledR} / \text { SULZER Medica }^{\circledR} \text { ) }\end{array}$ & $2.3 \%(n=3)$ \\
\hline $\begin{array}{c}\text { Alloclassic }^{\circledR} \text { high-carbon Metasul }{ }^{\circledR} \text { modular cup (Allopro }{ }^{\circledR} / \text { SULZER Medica }{ }^{\circledR} \text { ) } \\
\text { paired with high-carbon Metasul }{ }^{\circledR} \text { head (Protek }{ }^{\circledR} / \text { SULZER Medica }^{\circledR} \text { ) }\end{array}$ & $0.8 \%(\mathrm{n}=1)$ \\
\hline Low-Carbon $\mathrm{Co}_{28} \mathrm{Cr}_{6} \mathrm{Mo}$ Sliding Pairings & $(\mathrm{n}=17)$ \\
\hline \multicolumn{2}{|l|}{$\begin{array}{l}\text { - BICON }{ }^{\circledR} \text { low-carbon modular cup (PLUS Endoprosthetics }{ }^{\circledR} \text { ) } \\
\text { paired with low-carbon metal head (PLUS Endoprosthetics }{ }^{\circledR} \text { ) }\end{array}$} \\
\hline Undocumented $\mathrm{Co}_{28} \mathrm{Cr}_{6} \mathrm{Mo}$ Sliding Pairings & $(n=3)$ \\
\hline $\begin{array}{l}\cdot \text { Alloclassic }^{\circledR} \text { high-carbon Metasul }{ }^{\circledR} \text { modular cup } \\
\left(\text { Allopro }^{\circledR} / \text { SULZER Medica }{ }^{\circledR} \text { ) paired with undocumented metal head }\right.\end{array}$ & \\
\hline
\end{tabular}

${ }^{\mathrm{a} C o n s o l i d a t e d ~ v a l u e s ; ~}{ }^{\mathrm{b}}$ As the three types of high-carbon sliding pairings are absolutely identical in terms of geometry, alloy, tribology, and metallurgy they were consolidated to form one high-carbon study group.

In the low-carbon study group one (7.1\%) patient was lost to follow-up and clinical and radiological followup of $16(94.1 \%)$ arthroplasties in 13 patients was possible. The mean duration of clinical and radiological follow-up of the low-carbon group was $2.9 \mathrm{y}(\mathrm{n}=16$, range $1.0 \mathrm{y}$ to $4.8 \mathrm{y}, \mathrm{SD} \pm 1.3 \mathrm{y})$.

With the 3 undocumented metal-on-metal articulations, 2 patients with 2 (66.6\%) arthroplasties were lost to follow-up and clinical as well as radiological follow-up of only 1 (33.3\%) arthroplasty was thus possible. The duration of clinical and radiological follow-up of the undocumented articulation was $5.4 \mathrm{y}$.

Within the three groups, a consolidated total of 109 arthroplasties could thus be considered for detailed evaluation. As the carbon-content of the undocumented sliding pairing is unknown, the third study group was not included in statistical comparisons.

Standard antero-posterior pelvic radiographs of all patients were systematically reviewed for development and the expression of postoperative periprosthetic HO. The radiological findings were classified after Brooker et al. (see Table 4) [45].

Native blood samples for the HR ICP-MS and the evaluation of serum creatinine were taken from the cubital vein of the non-dominant upper extremity. A standardized protocol for the withdrawal of blood was strictly followed and all samples were taken by the same person using a standardized sample kit in order to equally distribute any inevitable heavy metal contamination caused by the needle, syringe or any part of the kit, All samples were frozen immediately and stored at $-20^{\circ} \mathrm{C}$ until they were analysed in one batch.

According to current knowledge, cobalt, chromium, and molybdenum ions or respective metallic compounds are excreted renally [46]. Hence, renal function was rated with all our patients by evaluating serum creatinine and calculating the estimated creatinine clearance according to Cockroft and Gault [47].

Metal analyses on cobalt, chromium, and molybdenum were performed using HR ICP-MS as detection thresholds for most elements are in the sub-parts per billion (ppb) or sub-parts per trillion ranges. In turn and as a consequence of the low detection thresholds, Class 1000 clean room facilities ensured contamination-free sample preparation [27] [48] [49]. A double focusing HR ICP-MS Finnigan MAT $^{\circledR}$ (element analysis package) was used in medium mode (resolution 3400) following a United Kingdom Accreditation Service (UKAS) accredited method (standard operating conditions see Table 5).

For all statistical evaluations, our data were assumed to represent a symmetric random sample from a normal population. The distribution of values and features between the low-carbon and the high-carbon study group were statistically analysed by non-parametric Mann-Whitney tests using SPSS ${ }^{\circledR}$ v10.0. For all analyses, the level of significance was set to $p<0.05$.

\section{Results}

The evaluation of the standard antero-posterior radiographs showed a point prevalence of postoperative periprosthetic HO as shown in Table 6. None of the patients showed severe bridging formations of ectopic bone 
Table 4. Classification of postoperative periprosthetic HOs after Brooker et al.

\begin{tabular}{|c|c|}
\hline Class 0 & No ossifications. \\
\hline - Class I & Islands of bone within the periarticular soft tissues. \\
\hline • Class II & $\begin{array}{c}\text { Bone spurs from the pelvis and/or proximal end of the femur (greater trochanter), } \\
\text { leaving } \geq 1 \mathrm{~cm} \text { between opposing surfaces. }\end{array}$ \\
\hline - Class III & $\begin{array}{l}\text { Bone spurs from the pelvis and/or proximal end of the femur (greater trochanter), } \\
\text { reducing the space between opposing bone surfaces to }<1 \mathrm{~cm} \text {. }\end{array}$ \\
\hline - Class IV & Apparent ankylosis of the hip. \\
\hline
\end{tabular}

Table 5. Standard operating conditions of the HR ICP-MS Finnigan MAT ${ }^{\circledR}$ on native blood.

\begin{tabular}{|c|c|}
\hline Torch Type & Fixed \\
\hline - Injector & Quartz, diameter $1.5 \mathrm{~mm}$ \\
\hline - Spray Chamber & Scott-type, double pass \\
\hline • Spray Chamber Temperature & $5^{\circ} \mathrm{C}$ \\
\hline • Cones & High-sensitivity platinum \\
\hline • Resolution & Medium, 3400 \\
\hline \multirow[t]{4}{*}{$\cdot$ Mass, $m / z$} & Chromium \\
\hline & Cobalt \\
\hline & Nickel \\
\hline & Molybdenum \\
\hline - Integration Type & Average \\
\hline - Scan Type & E-scan \\
\hline - Scan Window & $150 \%$ \\
\hline • Peak Search Window & $80 \%$ \\
\hline - Integration Window & $50 \%$ \\
\hline - Sample Time & $5 \mathrm{~ms}$ \\
\hline - Samples per Peak & 60 \\
\hline - Number of Repeats & 6 \\
\hline • Nebulization Gas Flow & $1.05 \mathrm{l} / \mathrm{min}$ \\
\hline - Auxiliary Gas Flow & $0.8 \mathrm{l} / \mathrm{min}$ \\
\hline - Carrier Gas Flow & $14.0 \mathrm{l} / \mathrm{min}$ \\
\hline • Power & $1100 \mathrm{~W}$ \\
\hline - Guard Electrode & Yes \\
\hline • Nebulizer & Cross-flow \\
\hline
\end{tabular}

\section{Table 6. Prevalence of postoperative periprosthetic HOs after THA.}

\begin{tabular}{|c|c|c|c|}
\hline \multirow{2}{*}{ Brooker Classes } & High-Carbon & Low-Carbon & Undocumented \\
\hline & $(\mathrm{n}=92)$ & $(n=16)$ & $(\mathrm{n}=1)$ \\
\hline - None/Brooker 0 & $52.2 \%(\mathrm{n}=48)$ & $68.8 \%(n=11)$ & $0 \%$ \\
\hline • Brooker I & $31.5 \%(n=29)$ & $25.0 \%(n=4)$ & $0 \%$ \\
\hline - Brooker II & $10.9 \%(n=10)$ & $0 \%$ & $0 \%$ \\
\hline - Brooker III & $5.4 \%(n=5)$ & $6.3 \%(n=1)$ & $100 \%(n=1)$ \\
\hline - Brooker IV & $0 \%$ & $0 \%$ & $0 \%$ \\
\hline
\end{tabular}


(Brooker class IV). Between low-carbon and high-carbon articulations no significant differences in the distribution of periprosthetic HO were found ( $\mathrm{n}=108, p=0.202)$.

A total of 6 patients with $n=6$ high-carbon articulations showed estimated creatinine clearances below the commonly accepted age and gender-dependent minimum thresholds (see Figure 1 and Table 7). With the respective patients, the following metal evaluations were considered as wrongly high or at least as inaccurate. The HR ICP-MS results of the respective patients were thus ignored, leaving $n=86$ arthroplasties in the high-carbon study group for further evaluations.

The evaluation of cobalt, chromium and molybdenum levels in native blood showed generally higher metal levels with low-carbon articulations (see Figure 2 and Table 8). A comparison of the mean metal levels between low-carbon and high-carbon articulations showed highly significant differences for cobalt $(\mathrm{n}=102, p=$ $0.006)$ and chromium $(n=102, p=0.003)$. Surprisingly, patients with primary THA showed unanimously higher metal levels compared to primary and secondary revisions. With two patients, we detected massively elevated metal levels (cobalt $66.80 \mu \mathrm{g} / \mathrm{l}$ and $15.43 \mu \mathrm{g} / \mathrm{l}$; chromium $41.6 \mu \mathrm{g} / \mathrm{l}$ and $5.14 \mu \mathrm{g} / \mathrm{l}$ ). Both patients had received bilateral high-carbon metal-on-metal articulations. While none of these patients suffers from renal failure, both have a history of unilateral prosthetic dislocation in full internal rotation. The patient showing the highest metal level is a lab technician in the production of colourings and textile dyes (which do contain high levels of metal), therefore, the respective heavy metal levels might not be related solely to THA.

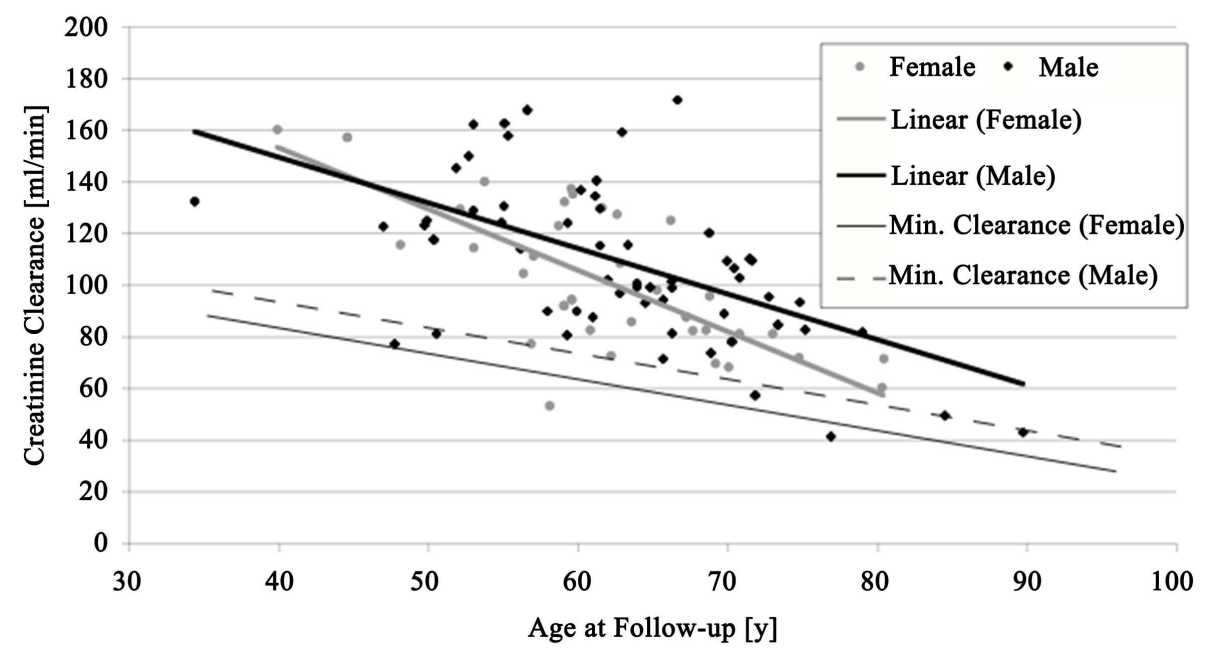

Figure 1. Scatter plot of the creatinine clearance versus the age at follow-up, as well as the respective linear regression for male $(n=69)$ and female patients $(n=40)$. The results show the agedependent decrease in renal function, as it was to be expected. Six patients ( $n=6$ arthroplasties) showed creatinine clearances beyond the reference minimum clearances. Their evaluations of metal levels were thus not considered with this study.

Table 7. Minimum creatinine clearances for the evaluation of renal functioning.

\begin{tabular}{cccc}
\hline \multicolumn{2}{c}{ For Male Patients } & \multicolumn{2}{c}{ For Female Patients } \\
\hline Age $[\mathrm{y}]$ & Creatinine Clearance $[\mathrm{ml} / \mathrm{min}]$ & Age $[\mathrm{y}]$ & Age $[\mathrm{y}]$ \\
$\leq 30$ & 110 & $\leq 30$ & 95 \\
$\leq 40$ & 100 & $\leq 40$ & 85 \\
$\leq 50$ & 90 & $\leq 50$ & 75 \\
$\leq 60$ & 80 & $\leq 60$ & 65 \\
$\leq 70$ & 70 & $\leq 70$ & 55 \\
$\leq 80$ & 60 & $\leq 80$ & 45 \\
$\leq 90$ & 50 & $\leq 90$ & 35 \\
$\leq 100$ & 40 & $\leq 100$ & 25 \\
$\leq 110$ & 30 & $\leq 110$ & 15 \\
\hline
\end{tabular}




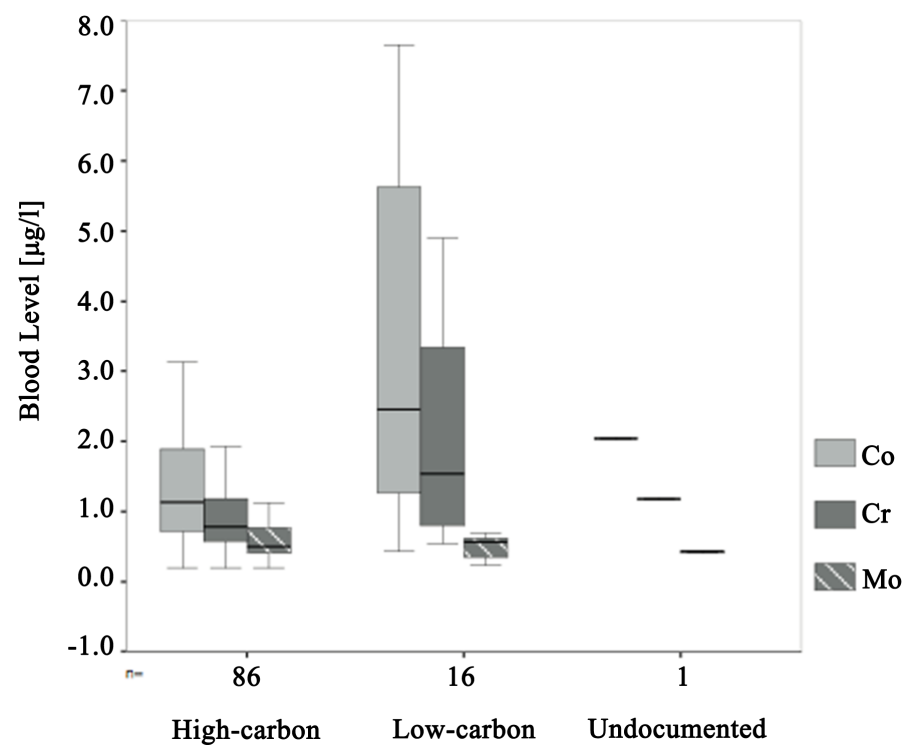

Figure 2. Distribution of cobalt, chromium, and molybdenum levels in native blood within the patients of the three study groups $(n=103)$ detected by double focusing high-resolution inductively coupled plasma mass spectrometry (HR ICP-MS) at a mean follow-up time of $3.9 \mathrm{y}$ (range 0.9 to $5.9 \mathrm{y}, \mathrm{SD} \pm 1.3 \mathrm{y}$ ). The mean cobalt, as well as the mean chromium levels differ significantly between the high-carbon and low-carbon study group $(\mathrm{n}=102, p=0.006$, and $p=0.003$ respectively). For molybdenum no significant differences were found $(\mathrm{n}=102, p=0.397)$.

Table 8. HR ICP-MS on cobalt, chromium, and molybdenum in native blood.

\begin{tabular}{|c|c|c|c|c|}
\hline & & High-carbon & Low-carbon & Undocumented \\
\hline & & $(\mathrm{n}=86)$ & $(\mathrm{n}=16)$ & $(\mathrm{n}=1)$ \\
\hline Mean Cobalt Level $[\mu \mathrm{g} / 1]^{\mathrm{a}}$ & & 2.55 & 3.11 & 2.04 \\
\hline $\mathrm{SD}[\mu \mathrm{g} / 1]$ & \pm & 7.37 & 2.57 & \\
\hline 95\% Confidence & Lower Bound & 0.97 & 1.84 & \\
\hline Interval $[\mu \mathrm{g} / 1]^{\mathrm{b}}$ & Upper Bound & 4.13 & 4.37 & \\
\hline \multirow[t]{2}{*}{ Range $[\mu \mathrm{g} / 1]$} & $\min$. & 0.2 & 0.44 & \\
\hline & $\max$. & 66.8 & 7.66 & \\
\hline Mean Chromium Level $[\mu \mathrm{g} / 1]^{\mathrm{a}}$ & & 1.58 & 2.17 & 1.18 \\
\hline $\mathrm{SD}[\mu \mathrm{g} / 1]$ & \pm & 4.47 & 1.6 & \\
\hline 95\% Confidence & Lower Bound & 0.62 & 1.32 & \\
\hline Interval $[\mu \mathrm{g} / 1]^{b}$ & Upper Bound & 2.53 & 3.02 & \\
\hline \multirow[t]{2}{*}{ Range $[\mu \mathrm{g} / 1]$} & $\min$. & 0.2 & 0.55 & \\
\hline & $\max$. & 41.6 & 4.9 & \\
\hline Mean Molybdenum Level $[\mu \mathrm{g} / 1]^{\mathrm{a}}$ & & 0.6 & 0.5 & 0.43 \\
\hline $\mathrm{SD}[\mu \mathrm{g} / 1]$ & \pm & 0.33 & 0.16 & \\
\hline 95\% Confidence & Lower Bound & 0.53 & 0.41 & \\
\hline Interval $[\mu \mathrm{g} / 1]^{b}$ & Upper Bound & 0.67 & 0.58 & \\
\hline \multirow[t]{2}{*}{ Range $[\mu \mathrm{g} / 1]$} & $\min$. & 0.2 & 0.24 & \\
\hline & max. & 2.56 & 0.66 & \\
\hline
\end{tabular}

${ }^{\mathrm{a}}$ Detection threshold for all evaluations at $0.20 \mu \mathrm{g} / \mathrm{l} .{ }^{\mathrm{b}}$ At the $95 \%$ confidence interval, the uncertainty is estimated at $\pm 20 \%$ of the reported values, and will increase to $\pm 50 \%$ for values close to the detection threshold. 
Separate evaluations (see Figure 3 and Figure 4) were carried out according to the carbon-content of the different combinations like metal-on-metal articulations versus contralateral asymptomatic hips, metal-on-metal articulations versus contralateral osteoarthritis, metal-on-metal articulations versus contralateral primary THA with metal-on-metal or metal-on-UHMW-PE or ceramic-on-UHMW-PE articulation, metal-on-metal articulation versus revision surgery with metal-on-metal or metal-on-UHMW-PE or ceramic-on-UHMW-PE articulation [50]. Patients with bilateral THA all show increased metal levels in native blood with the exception of ceramic-on-UHMW-PE articulations. With bilateral high-carbon and low-carbon metal-on-metal articulations the median levels of cobalt and chromium were not just doubled but rather tripled (elevated by a factor 2.7 to 3.2).

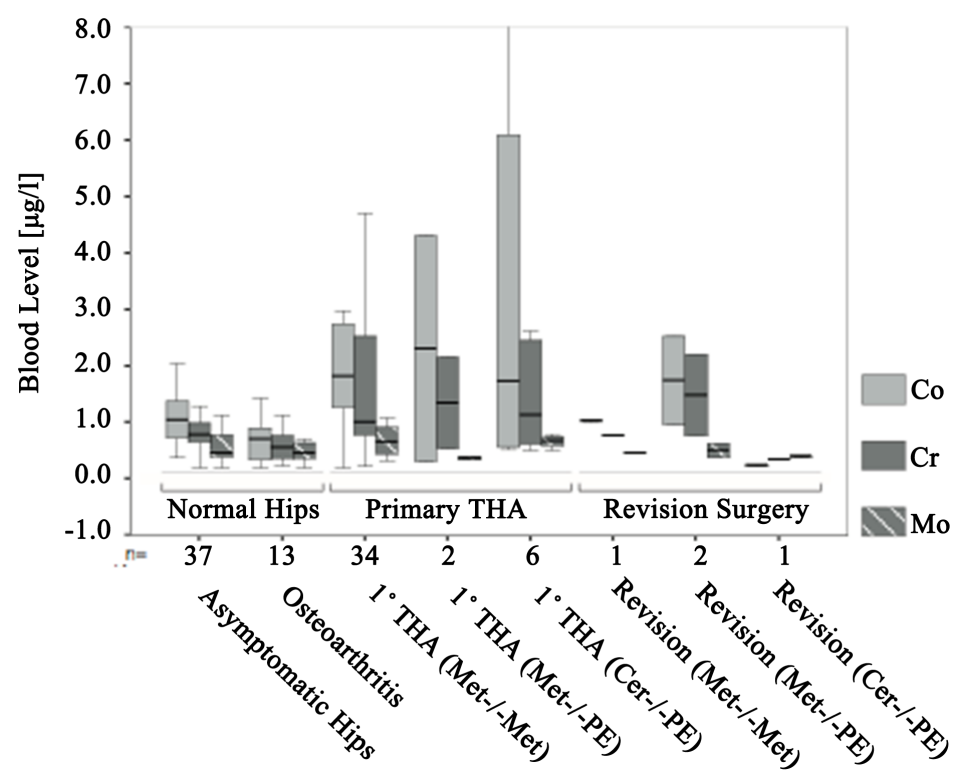

Figure 3. High-carbon articulations $(n=86)$ : distribution of cobalt, chromium, and molybdenum levels in native blood versus the clinical condition of the contralateral hip at a mean duration of follow-up of $4.1 \mathrm{y}$ (range $0.9 \mathrm{y}$ to $5.9 \mathrm{y}, \mathrm{SD} \pm 1.2 \mathrm{y}$ ).

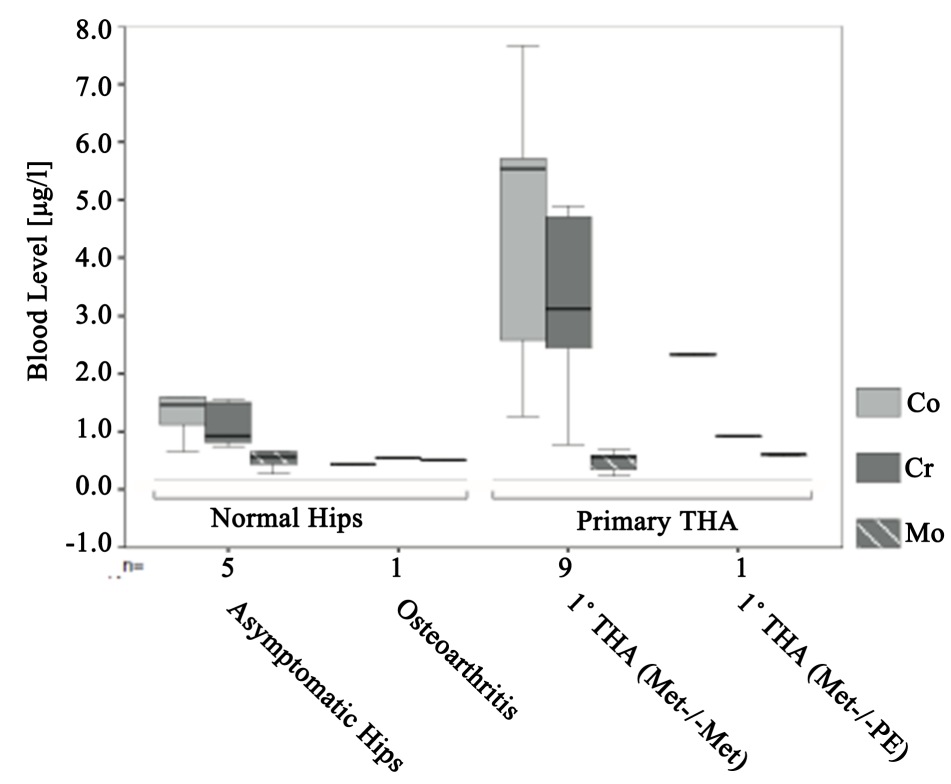

Figure 4. High-carbon articulations $(n=16)$ : distribution of cobalt, chromium, and molybdenum levels in native blood versus the clinical condition of the contralateral hip at a mean duration of follow-up of $2.9 \mathrm{y}$ (range $1.0 \mathrm{y}$ to $4.8 \mathrm{y}, \mathrm{SD} \pm 1.3 \mathrm{y}$ ). 
Large differences were found between the median metal levels of the high-carbon and low-carbon study groups with bilateral metal-on-metal articulation ( $p=0.034$ for cobalt, $p=0.016$ for chromium). In comparison to the high-carbon group, bilateral low-carbon articulations showed median cobalt and chromium levels increased by 3 and molybdenum levels increased by 1.2. However, the molybdenum levels seem to undulate between 0.5 and $0.8 \mu \mathrm{g} / \mathrm{l}$ independent to the carbon content, surgery performed, and the duration of follow-up.

The distribution of metal levels in native blood versus the point prevalence and the severity of postoperative periprosthetic HO revealed a balanced picture (see Figure 5 and Figure 6), although significant differences in metal levels between the high-carbon and the low-carbon study group were found. High-carbon articulations showed lower median metal levels in comparison to low-carbon sliding pairings. Arthroplasties without ossify-

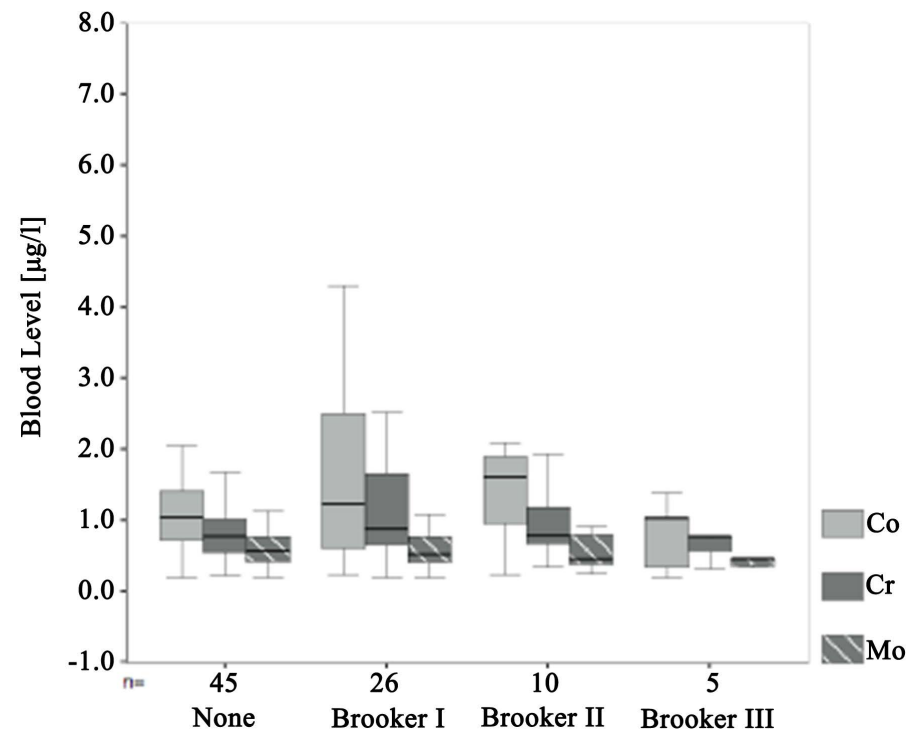

Figure 5. High-carbon articulations ( $\mathrm{n}=86$ ): cobalt, chromium and molybdenum levels versus periprosthetic HOs classified after Brooker et al. [26] at a mean duration of followup of $4.1 \mathrm{y}$ (range $0.9 \mathrm{y}$ to $5.9 \mathrm{y}, \mathrm{SD} \pm 1.2 \mathrm{y}$ ).

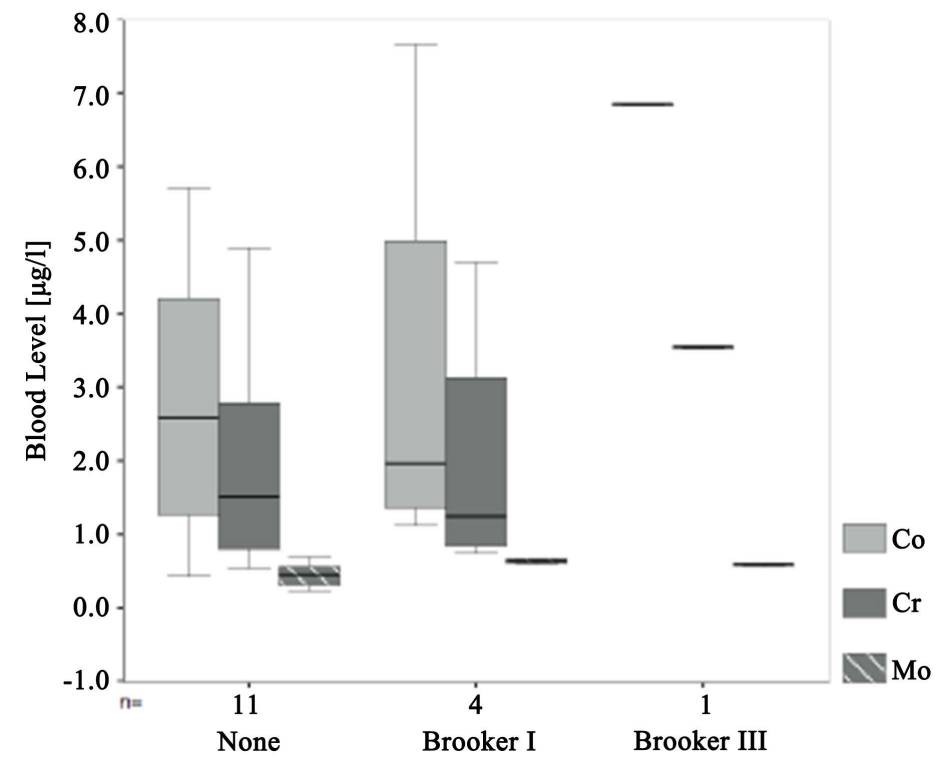

Figure 6. Low-carbon articulations $(n=16)$ : cobalt, chromium and molybdenum levels versus periprosthetic HOs classified after Brooker et al. [26] at a mean duration of followup of $2.9 \mathrm{y}$ (range $1.0 \mathrm{y}$ to $4.8 \mathrm{y}, \mathrm{SD} \pm 1.3 \mathrm{y}$ ). 
cations (Brooker class O) differed significantly with cobalt and chromium $(\mathrm{n}=56, p=0.033$ and $p=0.015$, respectively) but not with molybdenum. Arthroplasties with ossifications class I after Brooker revealed no significant differences, though the median levels differ conspicuously. Articulations with Brooker classes II and III were statistically not comparable.

\section{Discussion}

The reported prevalence of HO after THA varies considerably in the current literature. Formations of postoperative ectopic bone are described in $5 \%$ to $90 \%$ of all patients, whereas only $10 \%$ to $27 \%$ are clinically relevant regardless to their etiology. Eulert et al. evaluated a patient collective prospectively which did not receive any non-steroidal anti-inflammatory drugs (NSAIDs) and found a point prevalence of postoperative HO after THA of $63.7 \%$ [31]. Severe bridging formations or ankylosis are only seen with $2 \%$ to $3 \%$ of all patients at risk [32] [40] [51]. Overall, 45.9\% of the THA patients included in this study developed postoperative periprosthetic HO, but none of them showed restricted mobility or poor prosthetic performance.

The influence of surgical approaches on the development of postoperative HO is a controversial issue [29] [39]. Our data contribute no distinct patterns to this topic. A study by Schara and Herman came to the same conclusion supporting our results [52].

Systemic release of heavy metal ions, metallic compounds and corrosion products originating from THA with metal-on-metal articulation is well documented and remains as a legitimate cause of concern [19]-[22]. Except from large diameter head articulations there were only a few serious deleterious effects encountered up to now during the last 50 years. The low incidence of local and systemic adverse reactions to elevated metal levels after metal-on-metal THA stands in obvious contradiction to the possible harm that can be triggered by local accumulation and systemic distribution of metal debris. So far, two cases of renal tubular necrosis associated with massively elevated metal levels have been described [53]. Adverse reactions to metal debris tend to occur with less than $1 \%$ of the implanted prostheses [27], at least with small diameter heads. On the contrary, severe cases of inflammatory response have been reported recently [23]-[28]. The only clinical study specifically reporting the incidence of cancer in patients after metal-on-metal THA (of the low-carbon McKee-Farrar type) showed that the overall incidence for neoplasia is not affected by MoM total hip arthroplasties [54]. In contrast to the local accumulation of debris from UHMW-PE and $\mathrm{Al}_{2} \mathrm{O}_{3}$ ceramic articulations, the current $\mathrm{Co}_{28} \mathrm{Cr}_{6} \mathrm{Mo}_{28} \mathrm{~mm}$ heads seem to produce only that amount of metal debris that can be absorbed by the body and cleared via a specific however yet unknown renal clearance mechanism [12] [46] [50] [55] [56].

In the current literature, only few data on metal levels evaluated by the means of ICP-MS have been published yet. So far, only one study on serum metal levels was published by Favard et al. [57]. In general, measurements from native blood show slightly higher metal levels compared to investigations from serum. So it is not surprising that more publications about native blood levels do exist [48] [58]-[62]. Natural cobalt levels are reported to lie between 0.1 and $3.9 \mu \mathrm{g} / \mathrm{l}$. After MoM-THA they show a time-dependent increase to rather constant levels in the order of 0.1 to $13 \mu \mathrm{g} / \mathrm{l}$. A similar pattern is found for chromium showing natural chromium levels between 0.1 and $2.1 \mu \mathrm{g} / \mathrm{l}$ and a time-dependent increase after MoM-THA reaching up to 0.1 to $20.7 \mu \mathrm{g} / \mathrm{l}$.

There are indicators that the additional release of metal ions is related to the implant design and micromovements within modular implants like in acetabular backings, adapter sleeves and taper junctions. With respect to the amount of metal debris the carbon content is of minor importance [48].

Hardly any data on molybdenum levels are available. According to our results molybdenum levels are rather constant at 0.1 to $1.9 \mu \mathrm{g} / \mathrm{l}$ over long time periods and are not altered by orthopedic devices, alloys or surgical procedures. This might be due to a highly efficient clearance mechanism for molybdenum.

Our median metal levels for high-carbon articulations compare favourably with median levels in the literature [48] [58]-[62] except for low-carbon articulations where no comparable data were found. We observed significantly higher cobalt and chromium levels in the low-carbon study group compared to the high-carbon group. Reasons for this may be: 1) differences in the duration of the follow-up in the high versus the low-carbon group, 2) the disproportionate number of THAs within both groups, 3) differences due to the carbon content in the surface properties, the wear behaviour and/or the corrosion behaviour and 4) other exogenous and endogenous sources of cobalt and chromium.

1) The mean duration of follow-up of the high-carbon and the low-carbon group differs by $\Delta=1.2$ years (high-carbon $4.1 \mathrm{y}$, range 1.0 to $5.9 \mathrm{y}$; low-carbon $2.9 \mathrm{y}$, range 0.9 to $4.8 \mathrm{y}$ ). Considering the mean follow-up 
time, any running-in or bedding-in wear should not interfere with our evaluations as it should not have existed any more at the time when our native blood samples were taken. Running-in wear was found in vitro [7] [63][66] and was considered to exist in vivo too [67]. Its relevance on metal ion levels could not be confirmed in a longitudinal five-year in vivo AAS study on cobalt levels [55].

2) Despite the large difference in the number of evaluated THAs $(\Delta=70)$ between the low- and high-carbon group, the respective difference was taken into account in our statistical evaluations. Our evaluations may be even too conservative (i.e. over-compensated) by applying the Mann-Whitney test. In fact, the significant differences in metal levels between low-carbon and high-carbon articulations may be even more distinct.

3) In 1991 Pilliar concluded that $\mathrm{Co}_{28} \mathrm{Cr}_{6} \mathrm{Mo}$ alloy articulations with higher carbon content might be superior to low-carbon alloy prostheses in terms of wear resistance. Two hip simulator studies on high-carbon versus low-carbon $\mathrm{Co}_{28} \mathrm{Cr}_{6} \mathrm{Mo}$ alloys both meeting the ASTM F-1537 standards showed small but significant differences in the volumetric wear rates in favour of high-carbon articulations [68]. He postulated that the fine ingot $\mathrm{M}_{7} \mathrm{C}_{3}$ carbides within the alloy and particularly within the main wear zone of the polished bearing surfaces are responsible for this superior wear behaviour [69]. Hence, it is possible, that the metal levels in the native blood of our patients depend on the carbon content of their hips in the same way as it has been demonstrated in vitro.

4) Exogenous uptake of chromium, cobalt, and molybdenum, effectively does indeed affect metal levels in native blood, and therefore confound the evaluation of metal levels. For the general population, such uptake could be the result of exposure to spray paints, colourings or textile dyes, various chromates, the excessive consumption of sea salt, the consumption of vegetables cultivated close to facilities of the galvanic industry, as well as the excessive use of cosmetics based on sea salt or heavy metal pigments. Therefore, at least patients with known vocational exposure to heavy metals, such as industrial painters or lab-technicians in the production of textile dyes were identified and respective elevations of metal levels were taken into account. Endogenous sources of chromium, cobalt, and molybdenum may affect metal levels in native blood as well. Such uptake could be the result of dental treatment, and surgical procedures.

The distributions of metal levels versus the prevalence and the development of periprosthetic HO show rather balanced patterns for the median cobalt, chromium, and molybdenum levels in native blood. Hence, the blood levels of these ions do not have a significant impact on the development of postoperative HOs. Moreover, the carbon content does also not contribute to HOs since despite the fact that we observed significantly higher median cobalt and chromium levels in the low-carbon group compared to the high carbon group, this difference was not reflected in the degree of HOs. So, our results do not support any contribution of elevated metal levels to the formation of ectopic bone as suggested by H.G. Willert and K. Bachfischer et al. [43] [44]. Their patients are included in a muti-center study and they received a threaded Hofer-Imhof ${ }^{\circledR}$ titanium cups with a modular $4^{\circ}$ $\mathrm{Co}_{28} \mathrm{Cr}_{6} \mathrm{Mo}$ full-metal taper inlay. In $66 \%$ of their cases postoperative $\mathrm{HO}$ was developed. In contrary, our patients all received polyethylene backed modular or monobloc cups with metal articulation liner. It thus can be speculated that the additional metal-metal interface between inlay and cup (titanium against $\mathrm{Co}_{28} \mathrm{Cr}_{6} \mathrm{Mo}$ ) of the Hofer-Imhof ${ }^{\circledR}$ cups may account for additional metal debris or corrosion products, though this is far from proven. It is remarkable however that unlike our patients, all Bachfischer patients received a standardized NSAID prophylaxis (50 mg sodium-diclofenac per os tid for 7 days).

Given that approximately half of our patients developed postoperative ectopic bone formation prophylaxis against HO should be advised. Prophylaxis against HOs is performed either by pharmacotherapy or by pre- or postoperative radiation of the surgical site. The administration of prophylactic NSAIDs is widely practiced and accepted, whereas other drugs could not prove efficacy in preventing ectopic bone, though some promising experimental approaches with bone morphogenetic protein (BMP) antagonists have been made [70]. Radiation is considered only in revision cases where NSAID-prophylaxis has proven to be not effective enough.

The etiology of postoperative HOs is still unclear. According to our results elevated metal ion blood levels after MoM-THAs do not contribute significantly to the formation of HOs. In search of factors that may have an impact on the formation of HOs we may consider some parameters of our complete data records like the extent of the surgical trauma. It could be elucidated that a shorter time for the surgery correlates inversely with the development of HOs in our data set. Given that a comparative study on unilateral versus simultaneous bilateral arthroplasty revealed significant differences in the development for ectopic bone [71], the extent of soft tissue trauma could possibly play a role in heterotopic bone formation. Conversely, in support of this hypothesis, there are current clinical experiences and observations that in minimal invasive THA less or even no heterotopic bone is formed. 


\section{Acknowledgements}

Funds were received in support of the single-use material and the HR ICP-MS lab as described in this article from Zimmer, former Centerpulse Orthopedics Ltd., Baar/Winterthur (Switzerland).

\section{References}

[1] Cahoon, J.R., Bandyopadhya, R. and Tennese, L. (1975) The Concept of Protection Potential Applied to the Corrosion of Metallic Orthopedic Implants. Journal of Biomedical Materials Research, 9, 259-264. http://dx.doi.org/10.1002/jbm.820090302

[2] Cook, S.D., Kester, M.A., Harding, A.F., et al. (1986) Metallurgical Analysis of Five Failed Cast Cobalt-ChromiumMolybdenum Alloy Hip Prostheses. Journal of Rehabilitation Research \& Development, 23, 27-36.

[3] Sury, P. and Semlitsch, M. (1978) Corrosion Behavior of Cast and Forged Cobalt-Based Alloys for Double-Alloy Joint Endoprostheses. Journal of Biomedical Materials Research, 12, 723-741. http://dx.doi.org/10.1002/jbm.820120512

[4] Scott, R. (1998) Metal on Metal. In: Sedel, L. and Cabanela, M.E., Eds., Hip Surgery: Materials and Developments, Martin Dunitz, London.

[5] Semlitsch, M., Streicher, R.M. and Weber, H. (1989) The Wear Behavior of Capsules and Heads of CoCrMo Casts in Long-Term Implanted All-Metal Hip Prostheses. Orthopade, 18, 377-381.

[6] Oberholzer, S., Oehy, J., Rieker, C.B., et al. (1999) 10 Years of Metasul ${ }^{\circledR}$ : Competence in Tribology. Sulzer Medica, Winterthur.

[7] Rieker, C., Weber, H. and Schön, R. (1999) Development of the Metasul ${ }^{\circledR}$ Articulations. In: Rieker, C.B., Windler, M. and Wyss, U.B., Eds., METASUL ${ }^{\circledR}$ a Metal-On-Metal Bearing, Hans Huber, Bern.

[8] Schmidt, M., Weber, H. and Schon, R. (1996) Cobalt Chromium Molybdenum Metal Combination for Modular Hip Prostheses. Clinical Orthopaedics and Related Research, 35-47. http://dx.doi.org/10.1097/00003086-199608001-00004

[9] Weber, B.G. (1992) Metal-Metal Total Prosthesis of the Hip Joint: Back to the Future. Zeitschrift für Orthopädie und ihre Grenzgebiete, 130, 306-309. http://dx.doi.org/10.1055/s-2008-1039623

[10] Weber, B. (1999) METASUL ${ }^{\circledR}$ from 1988 to Today. In: Rieker, C.B., Windler, M. and Wyss, U.B., Eds., METASUL ${ }^{\circledR}$ a Metal-on-Metal Bearing, Hans Huber, Bern.

[11] Graf, R. (1997) Endoprothetik. In: Tschauner, C. and Anderhuber, F., Eds., Die Hüfte, Enke, Stuttgartl.

[12] Jacobs, J.J., Hallab, N., Urban, R., et al. (2001) Systemic Implications of Total Joint Replacement. In: Rieker, C.B., Oberholzer, S. and Wyss, U.B., Eds., World Tribology Forum in Arthroplasty, Hans Huber, Bern.

[13] Jacobs, J.J., Urban, R.M., Gilbert, J.L., et al. (1995) Local and Distant Products from Modularity. Clinical Orthopaedics and Related Research, 94-9105. http://dx.doi.org/10.1097/00003086-199510000-00010

[14] Lugowski, S.J., Smith, D.C., McHugh, A.D., et al. (1991) Release of Metal Ions from Dental Implant Materials in Vivo: Determination of Al, Co, Cr, Mo, Ni, V, and Ti in Organ Tissue. Journal of Biomedical Materials Research, 25, 1443-1458. http://dx.doi.org/10.1002/jbm.820251204

[15] Merritt, K., Brown, S.A. and Sharkey, N.A. (1984) Blood Distribution of Nickel, Cobalt, and Chromium Following Intramuscular Injection into Hamsters. Journal of Biomedical Materials Research, 18, 991-1004. http://dx.doi.org/10.1002/jbm.820180904

[16] Morscher, E.W., Hefti, A. and Aebi, U. (1998) Severe Osteolysis after Third-Body Wear Due to Hydroxyapatite Particles from Acetabular Cup Coating. Journal of Bone and Joint Surgery (British Volume), 80, 267-272. http://dx.doi.org/10.1302/0301-620X.80B2.8316

[17] Salvati, E.A. and Gomez-Barrena, E. (1998) Wear: Osteolysis Related to Metallic Debris. In: Sedel, L. and Cabanela, M., Eds., Hip Surgery: Materials and Developments, Martin Dunitz, London.

[18] Yang, J. and Merritt, K. (1994) Detection of Antibodies against Corrosion Products in Patients after Co-Cr Total Joint Replacements. Journal of Biomedical Materials Research, 28, 1249-1258. http://dx.doi.org/10.1002/jbm.820281102

[19] Howie, D.W., Rogers, S.D., McGee, M.A., et al. (1996) Biologic Effects of Cobalt Chrome in Cell and Animal Models. Clinical Orthopaedics and Related Research, 217-232. http://dx.doi.org/10.1097/00003086-199608001-00019

[20] Merritt, K. and Rodrigo, J.J. (1996) Immune Response to Synthetic Materials. Sensitization of Patients Receiving Orthopaedic Implants. Clinical Orthopaedics and Related Research, 71-79. http://dx.doi.org/10.1097/00003086-199605000-00009

[21] Tso, W.W. and Fung, W.P. (1981) Mutagenicity of Metallic Cations. Toxicology Letters, 8, 195-200. http://dx.doi.org/10.1016/0378-4274(81)90100-4 
[22] Waterman, A.H. and Schrik, J.J. (1985) Allergy in Hip Arthroplasty. Contact Dermatitis, 13, $294-301$. http://dx.doi.org/10.1111/j.1600-0536.1985.tb02581.x

[23] Baur, W., Hönle, W., Willert, H.G. and Schuh, A. (2005) Pathological Findings in Tissue Surrounding Revised Metal/Metal Articulations. Der Orthopäde, 34, 225-233. http://dx.doi.org/10.1007/s00132-004-0761-x

[24] Catelas, I. and Wimmer, M.A. (2011) New Insights into Wear and Biological Effects of Metal-on-Metal Bearings. The Journal of Bone \& Joint Surgery, 93, 76-83. http://dx.doi.org/10.2106/JBJS.J.01877

[25] Davies, A.P., Willert, H.G., Campbell, P.A., Learmonth, I.D. and Case, C.P. (2005) An Unusual Lymphocytic Perivascular Infiltration in Tissues around Contemporary Metal-on-Metal Joint Replacements. The Journal of Bone \& Joint Surgery, 87, 18-27. http://dx.doi.org/10.2106/JBJS.C.00949

[26] Beaulé, P.E. (2011) A Survey on the Prevalence of Pseudotumors with Metal-on-Metal Hip Resurfacing in Canadian Academic Centers. The Journal of Bone \& Joint Surgery, 93, 118-121.

[27] Skinner, J., Gie, G. and Kay, P. (2010) Metal on Metal Hip Replacement and Hip Resurfacing Arthroplasty: What Does the MHRA Medical Device Alert Mean? Proceedings of the British Orthopaedic Association.

[28] Watters, T.S., Eward, W.C., Hallows, R.K., Dodd, L.G., Wellman, S.S. and Bolognesi, M.P. (2010) Pseudotumor with Superimposed Periprosthetic Infection Following Metal-on-Metal Total Hip Arthroplasty: A Case Report. The Journal of Bone \& Joint Surgery, 92, 1666-1669. http://dx.doi.org/10.2106/JBJS.I.01208

[29] Bischoff, R., Dunlap, J., Carpenter, L., DeMouy, E. and Barrack, R. (1994) Heterotopic Ossification Following Uncemented Total Hip Arthroplasty. Effect of the Operative Approach. The Journal of Arthroplasty, 9, 641-644. http://dx.doi.org/10.1016/0883-5403(94)90118-X

[30] Eulert, J., Knelles, D. and Barthel, T. (1997) Heterotopic Ossifications. Der Unfallchirurg, 100, 667-674. http://dx.doi.org/10.1007/s001130050173

[31] Eulert, J., Knelles, D. and Barthel, T. (1997) Heterotopic Ossification. Der Orthopäde, 26, 399-406. http://dx.doi.org/10.1007/s132-1997-8285-5

[32] McKee, G.K. and Watson-Farrar, J. (1966) Replacement of Arthritic Hips by the McKee-Farrar Prosthesis. The Bone \& Joint Journal, 48, 245-259.

[33] Schafer, S.J., Schafer, L.O., Anglen, J.O. and Childers, M. (2000) Heterotopic Ossification in Rehabilitation Patients Who Have Had Internal Fixation of an Acetabular Fracture. Journal of Rehabilitation Research \& Development, 37, 389-393.

[34] Sell, S. and Schleh, T. (1999) C-Reactive Protein as an Early Indicator of the Formation of Heterotopic Ossifications after Total Hip Replacement. Archives of Orthopaedic and Trauma Surgery, 119, 205-207. http://dx.doi.org/10.1007/s004020050391

[35] Chen, T.H., Huang, C.K., Chen, W.M., Chiang, C.C. and Lo, W.H. (1998) Heterotopic Ossification after Cemented or Uncemented Bateman Bipolar Hemiarthroplasty. Chinese Medical Journal (Taipei), 61, 520-523.

[36] DeLee, J., Ferrari, A. and Charnley, J. (1976) Ectopic Bone Formation Following Low Friction Arthroplasty of the Hip. Clinical Orthopaedics and Related Research, No. 121, 53-59.

[37] Gierse, H., Scherberich, M. and Fuchs, S. (1994) Does the Type of Prosthesis Have an Effect on the Development of Periarticular Ossification? Zeitschrift für Orthopädie und Unfallchirurgie, 132, 516-520. http://dx.doi.org/10.1055/s-2008-1039480

[38] Kasetti, R.J., Shetty, A.A. and Rand, C. (2001) Heterotopic Ossification after Uncemented Hydroxyapatite-Coated Primary Total Hip Arthroplasty. The Journal of Arthroplasty, 16, 1038-1042. http://dx.doi.org/10.1054/arth.2001.25550

[39] Morrey, B.F., Adams, R.A. and Cabanela, M.E. (1984) Comparison of Heterotopic Bone after Anterolateral, Transtrochanteric, and Posterior Approaches for Total Hip Arthroplasty. Clinical Orthopaedics and Related Research, No. 188, 160-167.

[40] Ahrengart, L. (1991) Periarticular Heterotopic Ossification after Total Hip Arthroplasty. Risk Factors and Consequences. Clinical Orthopaedics and Related Research, No. 263, 49-58.

[41] Fahrer, H., Koch, P., Barandun, R., et al. (1988) Pelvic and Skeletal Hyperostosis (Diffuse Idiopathic Skeletal Hyperostosis, Forestier Disease). Zeitschrift für Rheumatologie, 47, 227-232.

[42] Kanis, J.A., Evanson, J.M. and Russell, R.G. (1981) Paget’s Disease of Bone: Diagnosis and Management. Metabolic Bone Disease and Related Research, 3, 219-230. http://dx.doi.org/10.1016/0221-8747(81)90036-9

[43] Bachfischer, K., Karpf, P.M. and Schwarz, R. (2000) An Unusual Observation of Total Hip Replacement with Meta on Metal Gliding Bearings. Zeitschrift für Orthopädie und Unfallchirurgie, 138, 230-234. http://dx.doi.org/10.1055/s-2000-10141

[44] Willert, H.G. (2003) Charakteristische Veränderungen im periprothetischen Gewebe revidierter Hüftendoprothesen mit 
Metall/Metall Gelenk lassen auf lokale Überempfindlichkeit schliessen. Proceedings of the Annual Meeting of the Swiss Society of Orthopaedic Surgery.

[45] Brooker, A.F., Bowerman, J.W., Robinson, R.A., Lee, H. and Riley, J.R. (1973) Ectopic Ossification Following Total Hip Replacement: Incidence and a Method of Classification. The Journal of Bone \& Joint Surgery, 55, 1629-1632.

[46] Daniel, J., Ziaee, H., Pradhan, C., Pynsent, P.B. and McMinn, D.J.W. (2010) Renal Clearance of Cobalt in Relation to the Use of Metal-on-Metal Bearings in Hip Arthroplasty. The Journal of Bone \& Joint Surgery, 92, 840-845. http://dx.doi.org/10.2106/JBJS.H.01821

[47] Cockcroft, D.W. and Gault, M.H. (1976) Prediction of Creatinine Clearance from Serum Creatinine. Nephron, 16, 31-41. http://dx.doi.org/10.1159/000180580

[48] Lavigne, M., Belzile, E.L., Roy, A., Morin, F., Amzica, T. and Vendittoli, P.-A. (2011) Comparison of Whole-Blood Metal Ion Levels in Four Types of Metal-on-Metal Large-Diameter Femoral Head Total Hip Arthroplasty: The Potential Influence of the Adapter Sleeve. The Journal of Bone \& Joint Surgery, 93, 128-136. http://dx.doi.org/10.2106/JBJS.J.01885

[49] Malviya, A., Ramaskandhan, J., Holland, J.P. and Lingard, E.A. (2010) Metal-on-Metal Total Hip Arthroplasty. The Journal of Bone \& Joint Surgery, 92, 1675-1683. http://dx.doi.org/10.2106/JBJS.I.01426

[50] Barceloux, D. (1999) Molybdenum. Journal of Toxicology: Clinical Toxicology, 37, 231-237. http://dx.doi.org/10.1081/CLT-100102422

[51] Ornsholt, J. and Espersen, J.O. (1975) Para-Articular Ossifications after Primary Prosthetic Replacement ad Modum Austin T. Moore. Acta Orthopaedica Scandinavica, 46, 643-650. http://dx.doi.org/10.3109/17453677508989246

[52] Schara, K. and Herman, S. (2001) Heterotopic Bone Formation in Total Hip Arthroplasty: Predisposing Factors, Classification and the Significance for Clinical Outcome. Acta Chirurgiae Orthopaedicae et Traumatologiae Čechoslovaca, 68, 105-108.

[53] Brodner, W., Grohs, J.G., Bitzan, P., Meisinger, V., Kovarik, J. and Kotz, R. (2000) Serum Cobalt and Serum Chromium Level in 2 Patients with Chronic Renal Failure after Total Hip Prosthesis Implantation with Metal-Metal Gliding Contact. Zeitschrift für Orthopädie und Unfallchirurgie, 138, 425-429. http://dx.doi.org/10.1055/s-2000-10172

[54] Visuri, T. and Koskenvuo, M. (1991) Cancer Risk after Mckee-Farrar Total Hip Replacement. Orthopedics, 14, 137142.

[55] Brodner, W., Bitzan, P., Meisinger, V., Kaider, A., Gottsauner-Wolf, F. and Kotz, R. (2003) Serum Cobalt Levels after Metal-on-Metal Total Hip Arthroplasty. The Journal of Bone \& Joint Surgery, 85-A, 2168-2173.

[56] Smith, T., Edmonds, C.J. and Barnaby, C.F. (1972) Absorption and Retention of Cobalt in Man by Whole-Body Counting. Health Physics, 22, 359-367. http://dx.doi.org/10.1097/00004032-197204000-00007

[57] Farvard, L. and Damie, F. (2001) Blood Serum Levels with Metal-Metal and Metal-Polyethylene Arthroplasties. In: Rieker, C.B., Oberholzer, S. and Wyss, U.B., Eds., World Tribology Forum in Arthroplasty, Hans Huber, Bern.

[58] Case, C.P., Ellis, L., Turner, J.C. and Fairman, B. (2001) Development of a Routine Method for the Determination of Trace Metals in Whole Blood by Magnetic Sector Inductively Coupled Plasma Mass Spectrometry with Particular Relevance to Patients with Total Hip and Knee Arthroplasty. Clinical Chemistry, 47, 275-280.

[59] Kim, P.R., Beaule, P.E., Dunbar, M., Lee, J.K.L., Birkett, N., Turner, M.C., Yenugadhati, N., Armstrong, V. and Krewski, D. (2011) Cobalt and Chromium Levels in Blood and Urine Following Hip Resurfacing Arthroplasty with the Conserve Plus Implant. The Journal of Bone \& Joint Surgery, 93, 107-117. http://dx.doi.org/10.2106/JBJS.J.01721

[60] Migaud, H., Putman, S., Krantz, N., Vasseur, L. and Girard, J. (2011) Cementless Metal-on-Metal versus Ceramic-onPolyethylene Hip Arthroplasty in Patients Less than Fifty Years of Age: A Comparative Study with Twelve to Fourteen-Year Follow-Up. The Journal of Bone \& Joint Surgery, 93, 137-142. http://dx.doi.org/10.2106/JBJS.J.01720

[61] Rieker, C. (2002) Co and Cr Concentration in Whole Blood/Serum of Patients Having Modern Metal-on-Metal Prostheses. Proceedings of the Annual Scientific Meeting of the Australian Orthopaedic Association.

[62] Weiss, R.L. and Jones-Moore, A.M. (2001) ARUP’s Guide to Clinical Laboratory Testing (CLT). ARUP Laboratories, Salt Lake City.

[63] Chan, F.W., Bobyn, J.D., Medley, J.B., Krygier, J.J. and Tanzer, M. (1999) The Otto Aufranc Award. Wear and Lubrication of Metal-on-Metal Hip Implants. Clinical Orthopaedics and Related Research, No. 369, 10-24.

[64] Firkins, P.J., Tipper, J.L., Ingham, E., Stone, M.H., Farrar, R. and Fisher, J. (2001) A Novel Low Wearing Differential Hardness, Ceramic-on-Metal Hip Joint Prosthesis. Journal of Biomechanics, 34, 1291-1298. http://dx.doi.org/10.1016/S0021-9290(01)00096-3

[65] Plitz, W., Huber, J. and Refior, H.J. (1997) Experimental Studies of Metal-Metal Slide Combinations and Their Value in Relation to Expected In-Vivo Behavior. Der Orthopäde, 26, 135-141. 
[66] Rieker, C., Konrad, R. and Schon, R. (2001) In Vitro Comparison of the Two Hard-Hard Articulations for Total Hip Replacements. Proceedings of the Institution of Mechanical Engineers, Part H, Journal of Engineering in Medicine, 215, 153-160. http://dx.doi.org/10.1243/0954411011533715

[67] Brodner, W., Bitzan, P., Meisinger, V., Kaider, A., Gottsauner-Wolf, F. and Kotz, R. (1997) Elevated Serum Cobalt with Metal-on-Metal Articulating Surfaces. The Bone \& Joint Journal, 79, 316-321.

[68] St. John, K.R., Poggie, R.A., Zardiackas, L.D. and Afflitto, R.M. (1999) Comparison of Two Cobalt-Based Alloys for Use in Hip Replacement: Evaluation of the Wear Properties in a Hip Simulator. In: Disegi, J.A., Kennedy, R.K. and Pilliar, R., Eds., Special Technical Publication 1365: Cobalt-Based Alloys for Biomedical Applications, American Society for Testing and Materials, West Conshohocken.

[69] Pilliar, R.M. (1991) Modern Metal Processing for Improved Load-Bearing Surgical Implants. Biomaterials, 12, 95-100. http://dx.doi.org/10.1016/0142-9612(91)90185-D

[70] Weber, F.E., Eyrich, G., Grätza, K.W., Thomas, R.M., Maly, F.E. and Sailer, H.F. (2001) Disulfide Bridge Conformers of Mature BMP Are Inhibitors for Heterotopic Ossification. Biochemical and Biophysical Research Communications, 286, 554-558. http://dx.doi.org/10.1006/bbrc.2001.5408

[71] Ritter, M.A. and Stringer, E.A. (1980) Bilateral Total Hip Arthroplasty: A Single Procedure. Clinical Orthopaedics and Related Research, No. 149, 185-190. 